\title{
PRECOPULATORY BEHAVIOUR, MATING AND SEX RATIO OF BLACK FLIES SIMULIUM LINEATUM (DIPTERA: SIMULIIDAE) UNDER NATURAL CONDITIONS
}

\author{
Vilma BAUŽIENĖ, Vincas BŪDA
}

Institute of Ecology of Vilnius University, Akademijos 2, LT-08412 Vilnius-21, Lithuania. E-mail: vilmajon@ekoi.lt, vinbuda@ekoi.lt

\begin{abstract}
Precopulatory and mating behaviour of stenogamous black fly species (Diptera: Simuliidae) Simulium lineatum (Meigen, 1984) was investigated under natural conditions. Polygynous males were found as single individuals or assembled in small aggregations ( $1.8 \pm 1.1$ individuals on average) on calami (above water height up to $50 \mathrm{~cm}$ ) or in larger aggregations on cattails (above water height up to $100 \mathrm{~cm}$ ). Females were found both among single males and aggregated. Males demonstrate precopulatory behaviour (approaching, touching, attempting to copulate) both towards the female and male. The duration of touching and attempting to copulate differed significantly and lasted on average for: $13.5 \pm 4.5 \mathrm{~s}$ when male interacted with a female and $6.9 \pm 2.4 \mathrm{~s}$ when interacted with a male. The mean duration of copulation was $5.4 \pm 1.1 \mathrm{~min}$. The sex ratio of $S$. lineatum during the adults flying period was malebiased: during the first half of the season the ratio was 1:1.08 (by $4 \%$ emerged more males), whereas during the second half of the period the ratio was $1: 1.4$, with a significant shift of towards males $(16 \%)$. Key words: mating, courtship behaviour, aggregation, polygyny, sex ratio
\end{abstract}

\section{INTRODUCTION}

Mating behaviour is among the least investigated areas in the biology of black flies. The general peculiarities (eurygamous or stenogamous) of mating behaviour are known for 38 (about 15\%) species of 250 North American ones (Adler et al. 2004) and for 27 ones of 571 palearctic species (Crosskey 1990; Usova 1980; Kaplich \& Skulovec 2000). The most data is collected on eurigamous species (air swarming and mating), whereas little is known about the mating behaviour of stenogamous species (forming aggregations and mating on a substrate). More detailed data on the mating behaviour of stenogamous species are limited to Cnephia dacotensis (Twin 1936; Nicholson \& Mickel 1950; Davies \& Peterson 1956), Crozetia crozetensis (Davies 1974) and S. decorum (Davies \& Peterson 1956) only. No comprehensive data exist on the mating behaviour of other stenogamous fly species. Adults of stenogamous species emerge sexually mature and mate immediately after emergence (Crosskey 1990).

Black fly females are monoandrous, while males are polygynous (Adler et al. 2004). A known exception is the complex of eurigamous species $S$. damnosum, females of which can copulate repeatedly (Boakye \& Mosha 1988). In Lithuania abundant blood-sucking species $S$. lineatum is the only stenogamous species of the genus Simulium known in Europe (Crosskey 1990). Initial studies on mating behaviour and spermatophore transmission in this species were already carried out under laboratory conditions (Baužienè et al. 2004). Studies on precopulatory behaviour (the elements of courtship) under natural conditions are needed not only to acquire a deeper insight into knowledge of species' biology, but for the development of bioassay for sex pheromone search in black flies as well.

The purpose of our study was to determine the peculiarities of precopulatory (size of aggregation, duration of courtship elements) and mating behaviour (duration) of $S$. lineatum adults under natural conditions and their sex ratio dynamics.

\section{Material AND MEthods}

Recording of mating behaviour. Mating behaviour of S. lineatum was recorded on 7 September 2005 from 9.30 to $11.00 \mathrm{a}$. m. on the coastwise of the Neris River near Žverrynas district (Vilnius, Lithuania). Adults were observed on the plants growing on the river islet $(1 \times$ $3 \mathrm{~m}$ ): cattails (Typha latifolia) and calami (Acorus calamus) supporting the newly emerged adults (sites of emergence were found near the islet). The height of the calami growing in the study area did not exceed $50 \mathrm{~cm}$, 
whereas the height of cattails (supporting larger aggregations of males) reached $100 \mathrm{~cm}$ and over above water surface. Air temperature fluctuated from +24 to $+26^{\circ} \mathrm{C}$. During observations, the size of black fly aggregation was evaluated: individuals of black flies crawling on plant leaves were counted and their sex was determined based on sufficiently marked differences in eye shape (Adler et al. 2004).

The following elements of precopulatory behaviour were observed: 1) approach (two types of the behaviour were recorded: either male and female approaches each other or male approaches a female at rest); 2) touching (male touches female with the foretarsi and moves sideways towards the thorax of female and finally mounts her for copulation; 3) an attempt to copulate (male bends the abdomen and tries to engage in genital contact).

The durations of of precopulatory (courtship) behaviour elements were recorded of five contacts male-to-female as well as male-to-male both on calamus leaves (in smaller aggregations consisting of not more than 2 or 3 black flies per leaf) and cattail leaves (in larger aggregations of at least 6 males per leaf). The duration of copulation, mating and male reaction to a copulating pair in a aggregation were recorded based on five copulating pairs of $S$. lineatum both on the leaves of cattail and calamus. The behaviour of a female and a male was also recorded at a postcopulatory stage.

The mating behaviour was filmed and the duration of its elements was analysed basing on records of chronometer of digital camera SONY (DCR-TRV285E; 20× optical, 990× digital zoom).

Identification of species. A number of the studied adults (about 70 specimen) were collected from the leaves of calami and cattails. The insects were fixed in a $70 \%$ ethanol and identified according to Yankovsky (2002).

Sex ratio. Pupae of black flies $S$. lineatum were collected for rearing adults in Lithuania (the Neris River, downstream of Vilnius city, close to Žvėrynas district) from early June to late September 2001-2003. The most of the pupae was found on sedge (Carex sp.) growing in water.

Pupae of $S$. lineatum were selected from mix of those of several species following identification according to Jensen (1997). Undamaged mature pupae (dark) were placed in glass vials of $3 \mathrm{ml}$ in volume. To maintain humidity in the vials, wet filter paper strips were applied. Vials were closed with wet paralon sponge plugs. Sex ratio of adults emerged from pupae was determined basing on clear eyes dimorphism (Yankovsky 2002). Statistical data processing. Data on mating behaviour were analysed using 'Statistica 5.0' programme. A $t$ test for independent variables was used to evaluate the significance of mean differences in the number of single and aggregated males collected from different plants, as well as differences between the mean duration of the elements of precopulatory behaviour demonstrated towards opposite- and the same-sex conspecifics. Statistical significance in sex ratio was evaluated by a $t$ test for dependent variables.

\section{Results}

Aggregations. Males of $S$. lineatum were found on the leaves of calami as single individuals or in small aggregations (consisting of not more than 4 individuals per leaf), with an average number of individuals making up $1.8 \pm 1.1\left(\mathrm{n}_{\text {aggregations }}=33, \mathrm{n}_{\text {males }}=58\right)($ Fig. 1$)$. Larger aggregations of males were found on the leaves of cattail, with an average number of individuals amounting to $6.0 \pm 3.3$ per leaf $\left(n_{\text {aggregations }}=24, n_{\text {males }}=144\right)$. Aggregation on cattail was significantly higher than that on calami leaves on average $(\mathrm{t}=-6.9, p<0.01)$.

Females of $S$. lineatum did not form aggregations. They were found both with a single and aggregated males (on calami: $\mathrm{n}_{\text {aggregations }}=33, \mathrm{n}_{\text {females }}=12$ ), as well as among larger male aggregations (on cattails: $\left.\mathrm{n}_{\text {aggregations }}=24, \mathrm{n}_{\text {females }}=10\right)$. Females mated with either single or aggregated male.

Coursthip behaviour. The duration of the latter two elements (touching and an attempt to copulate) was very short in time, thus precise enough recording their duration separately was complicated enough. For this reason they were recorded together. The duration of touching and copulation attempt depended on the sex of interacting flies (Fig. 2).

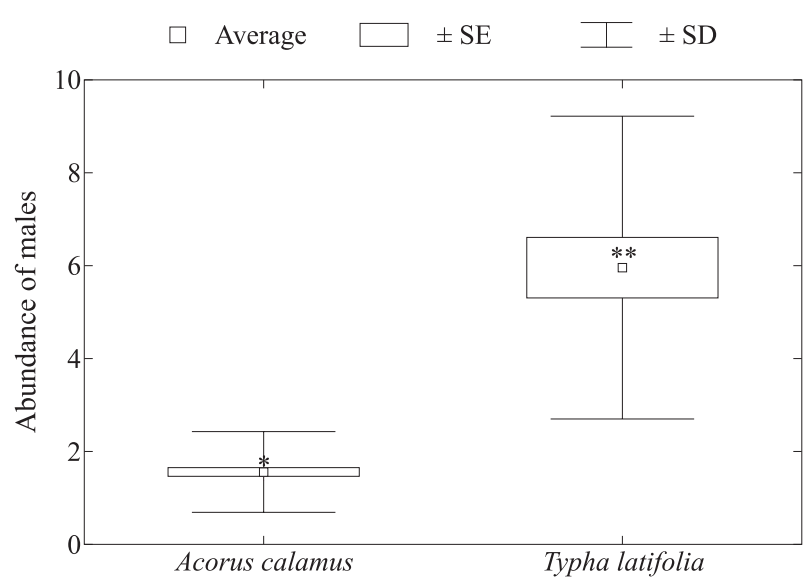

Figure 1. Abundance of Simulium lineatum males in aggregations on different plants. * - values marked by different number of stars differ significantly, $p<0.01$ ( $t$-test for independent variables). 
Male-to-male and male-to-female interaction. Males of S. lineatum demonstrate elements of courtship behaviour (approaching, touching and attempting to copulate) with same-sex individuals. No qualitative behavioural differences were observed in male-to-male interaction as compared to male and female interaction during courtship. However, quantitative differences were obvious. Two elements of behaviour (touching and copulation attempt) differed in duration, and those lasted from 4 to $11 \mathrm{~s}\left(6.9 \pm 2.4 \mathrm{~s}\right.$ on average, $\mathrm{n}_{\text {male-to- }}$ male $=5$ ) in male-to-male interaction (Fig. 2). The mean duration of male-to-male interaction was significantly shorter compare to that of male and female $(13.5 \pm$ $\left.4.5 \mathrm{~s}, \mathrm{n}_{\text {male-to-female }}=5\right)(\mathrm{t}=-4.1, p<0.01)$ (Fig. 2).

Copulation. The mean duration of copulation under natural conditions was $5.4 \pm 1.1 \mathrm{~min}\left(\mathrm{n}_{\text {pairs }}=10\right)$.

Male reaction to a copulating pair. A large number of black flies remained in an aggregation in copula. In larger aggregations, males that remained unmated demonstrated

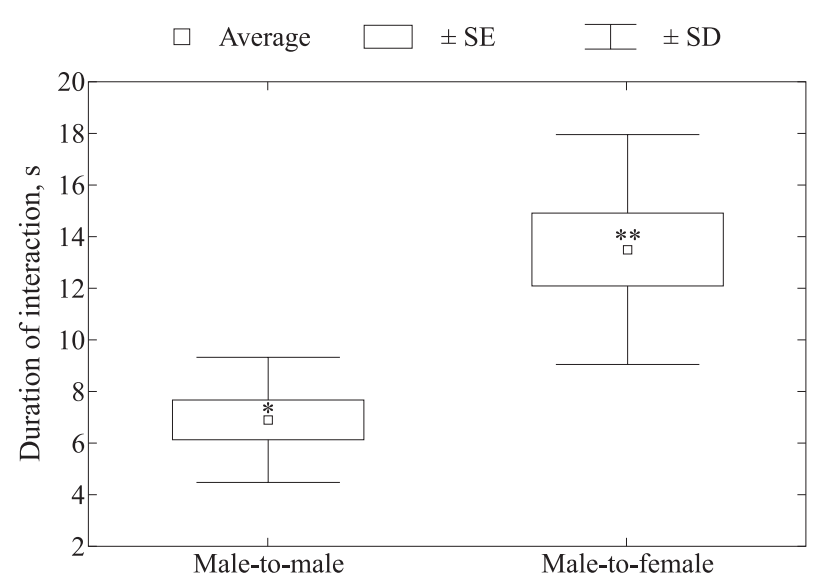

Figure 2. Duration of interaction of Simulium lineatum males with conspecific during courtship depending on sex.* values marked by different number of stars differ significantly, $p<0.01$ ( $t$-test for independent variables). their reaction towards a mating couple: approached it and attempted to copulate with any one of already copulating partners. The number of males responding in such way constituted from 5 to 11 individuals during the period when couple was mating $(5.4 \pm 1.1 \mathrm{~min})$. The duration of male's reaction (touching and attempting to copulate) towards a copulating pair lasted from 7 to $24 \mathrm{~s}(12.3 \pm 1.2 \mathrm{~s}$ on average, $\mathrm{n}=11)$, i.e. significantly longer compare to the same-sex interaction $(t=-2.6$, $p=0.02$ ), but the duration did not differ from that of male and female interaction $(\mathrm{t}=0.5, p=0.6)$.

Postcopulatory behaviour. Immediately after copulation (at an interval of just a few seconds), males made attempts to remate with the same female when that still stayed in an aggregation for some time. All such attempts $(n=10)$ to remate were unsuccessful. Among all recently mated females observed, no one repeatedly copulated. Further records of postcopulatory behaviour of females showed that they crawled to another part of a leaf with no male aggregation or flew away, but they remained with a single male in the same place, whereas single male that failed in re-mating flew away. Sex ratio. In total of 12,291 females and 15,730 males of $S$. lineatum black flies were reared under laboratory conditions over the period from 2001 to 2003. The ratio of the emerged females to males was $1: 1.28$. The number of emerged males exceeded that of females by $12 \%$ and the difference in the proportion was statistically significant $\left(\mathrm{t}=-3.12, p=0.03 ; \mathrm{n}_{\text {females }}=12,291\right.$; $\left.\mathrm{n}_{\text {males }}=15,730\right)$ (Table 1$)$. During the adult flying season (2001-2003), fluctuations in sex ratio were recorded: during the first half of the season, from early June to late July, female to male ratio accounted for 1:1.08, with just a 4\% shift towards males. The difference was not significant $\left(\mathrm{t}=-3.98, p=0.06 ; \mathrm{n}_{\text {females }}=4643\right.$; $\left.\mathrm{n}_{\text {males }}=5013\right)($ Table 1$)$. In the second half of the season, from early August to late September, the proportion of males increased (the difference made up 16\%) and sex ratio was 1:1.4 (Table 1). The difference in

Table 1. Sex ratio of Simulium lineatum adults (2001-2003).

\begin{tabular}{|c|c|c|c|c|c|c|c|c|c|}
\hline & \multicolumn{2}{|c|}{2001} & \multicolumn{2}{|c|}{2002} & \multicolumn{2}{|c|}{2003} & \multicolumn{2}{|c|}{ 2001-2003: } & \multirow[b]{2}{*}{ In total } \\
\hline & $\begin{array}{l}\text { I* half }^{*} \\
\text { of the } \\
\text { season }\end{array}$ & $\begin{array}{c}\text { II** half } \\
\text { of the } \\
\text { season }\end{array}$ & $\begin{array}{l}\text { I half } \\
\text { of the } \\
\text { season }\end{array}$ & $\begin{array}{l}\text { II half } \\
\text { of the } \\
\text { season }\end{array}$ & $\begin{array}{l}\text { I half } \\
\text { of the } \\
\text { season }\end{array}$ & $\begin{array}{l}\text { II half } \\
\text { of the } \\
\text { season }\end{array}$ & $\begin{array}{c}\text { I half } \\
\text { of the } \\
\text { seasons }\end{array}$ & $\begin{array}{l}\text { II half } \\
\text { of the } \\
\text { seasons }\end{array}$ & \\
\hline Females & 2,261 & 3,225 & 941 & 3,158 & 1,441 & 1,265 & 4,643 & 7,648 & 12,291 \\
\hline Males & 2,606 & 4,550 & 1,075 & 4,396 & 1,332 & 1,771 & 5,013 & 10,717 & 15,730 \\
\hline Sex ratio & $1: 1.15$ & $1: 1.4$ & $1: 1.14$ & $1: 1.4$ & $1: 0.9$ & $1: 1.4$ & $1: 1.08$ & $1: 1.4$ & $1: 1.28$ \\
\hline
\end{tabular}


Table 2. Emergence of adults and sex ratio of Simulium lineatum adults (2001).

\begin{tabular}{lccccccccc}
\hline Term & $\begin{array}{c}6-15 \\
\text { June }\end{array}$ & $\begin{array}{c}16-29 \\
\text { June }\end{array}$ & $\begin{array}{c}1-15 \\
\text { July }\end{array}$ & $\begin{array}{c}16-30 \\
\text { July }\end{array}$ & $\begin{array}{c}2-15 \\
\text { August }\end{array}$ & $\begin{array}{c}17-31 \\
\text { August }\end{array}$ & $\begin{array}{c}1-14 \\
\text { September }\end{array}$ & $\begin{array}{c}16 \text { Sep- } \\
\text { tember }-\end{array}$ & In total \\
\hline Females & 277 & 787 & 675 & 522 & 252 & 718 & 1,006 & 1,249 & 5,486 \\
Males & 233 & 774 & 745 & 854 & 439 & 1,115 & 1,754 & 1,242 & 7,156 \\
Sex ratio & $1: 0.8$ & $1: 0.98$ & $1: 1.1$ & $1: 1.6$ & $1: 1.7$ & $1: 1.6$ & $1: 1.7$ & $1: 1$ & $1: 1.3$ \\
\hline
\end{tabular}

sex ratio during the second half of the season was significant $\left(\mathrm{t}=-29.46, p=0.02 ; \mathrm{n}_{\text {females }}=7,648 ; \mathrm{n}_{\text {males }}=\right.$ 10,717).

A more thorough one-year analysis of $S$. lineatum population, when sex ratio was recorded at an interval of two weeks, revealed a slight shift towards females in the sex ratio at the very beginning of the flying season (in June). The remaining part of the season (over a three month period, from early July to mid-September) was dominated by males or sex ratio was close to one (over a two week period, from mid-September to early October) (Table 2).

\section{Discussion}

Aggregations. Males of $S$. lineatum were found in the same location either as single individuals or in smaller (on calamus) or larger aggregations (on cattail). Differences in substrate selection betwen males might be related to the height of plants above-water rather than to the characteristics of the leaf surface (chemical, physical). Height above-water is probably important factor for black flies while making aggregations. It is known, males of Cnephia dacotensis form aggregations on shore stones at a height of about $100 \mathrm{~cm}$ above water (Davies \& Peterson 1956).

Females of $S$. lineatum visited both calami and cattails supporting a single male or their aggregation. If probability for a virgin female to find a suitable mating partner among a cluster of males compare to single ones (i.e. if proportion of attempts-to-mate/successfulmatings) differ or not, remains to be investigated.

Courtship behaviour. In contrast to the duration of copulation, the precopulatory period (courtship behaviour, i.e. touching and copulation attempts) of $S$. lineatum is short and lasts approximately a quater of a minute $(13.5 \pm 4.5 \mathrm{~s})$. The data ascertained the duration of the courtship duration of the species under natural conditions, which was determined in earlier studies carried out under laboratory conditions as being less than 1 min (Baužienè et al. 2004).
Male-to-male interaction. The attempts of $S$. lineatum males to copulate with the same-sex individuals allow assuming that visual stimuli are not the only ones that play key role in recognition of a suitable partner. 'Errors' occurring in courtship behaviour (male attempts to copulate with same-sex conspecifics) are characteristic for Cnephia dacotensis (Nicholson \& Mickel 1950), as well as for some other dipterans (Drosophila melanogaster (Tompkins et al. 1980) and Chironomidae (Thornhill \& Alcock 1983). There are guesses that such behaviour is a result of inter-sexual competition and its aim is to disturb a competitor. Significant differences in the duration of mating behaviour of $S$. lineatum show that the duration of courtship behaviour demonstrated by male towards another male (misleading behaviour) was shorter $(6.9 \pm 2.4 \mathrm{~s})$ than that demonstrated by male towards female $(13.5 \pm 4.5 \mathrm{~s})$, i. e. a male recognises a partner as unsuitable for mating quite soon (approximately in $7 \mathrm{~s}$ ).

Copulation. After a successful short precopulatory period, much longer copulation period starts. Mean duration of $S$. lineatum copulation in nature $(5.4 \pm$ $1.1 \mathrm{~min})$ is in line with mean duration of copulation recorded under laboratory conditions: $5.6 \pm 2.7 \mathrm{~min}$ $\left(\mathrm{n}=356\right.$, at $\left.+27-29^{\circ} \mathrm{C}\right)$ and $4.4 \pm 1.5 \mathrm{~min}(\mathrm{n}=297$, at $+29-32^{\circ} \mathrm{C}$ ) (Baužienè et al. 2004).

Postcopulatory behaviour. When mated, all $S$. lineatum males demonstrated attempts to mate again. In contrast to females, they are ready to copulate repeatedly (i. e. exhibit mating behaviour) in a very short time (just seconds) after first copulation. It is obvious that polygynous males fiercely compete for females. The competition becomes more intense due to the increased number of males in the natural population (from 4 to $16 \%$ ). Male-biased sex ratio is confirmed by differences in sex ratio dynamics that become particularly apparent in the second half of the adult flying season (from midJuly to late September) as it was established in 20012003. This is the time when more males emerge and sex ratio accounts for 1:1.4. In conclusion, we can state that an intensive male sex selection in the second half of the season becomes even more apparent (namely 
during this period courtship and mating behaviour was registered in the present research).

The records on $S$. lineatum courtship and mating behaviour carried out under natural conditions provided new data that can be used to arrange bioassay for sex pheromone search in this species.

\section{ACKNOWLedgements}

The authors greatly acknowledge the help of Dr Rasa Bernotienė, Institute of Ecology, Vilnius University, for identifying black fly species. Many thanks are also due to Mr. Kęstutis Verbickas for filming under natural conditions. Part of these studies was supported by the Lithuanian Science and Studies Foundation (No T-493, 2000-2001).

\section{REFERENCES}

Adler, P. H., Currie, D. C. and Wood, D. M. (eds) 2004. The Black Flies (Simuliidae) of North America. Ithaca, New York: Cornell University.

Baužienė, V., Būda, V. and Bernotienė, R. 2004. Mating activity of the mammalophilic blackflies Simulium (Wilhelmia) lineatum (Meigen, 1984) (Diptera: Simuliidae) under laboratory conditions. Acta Zoologica Lithuanica 14 (4): 34-40.

Boakye, D. A. and Mosha, F. W. 1988. Natural hybridisation between Simulium sanctipauli and S. sirbanum, two sibling species of the $S$. damnosum complex. Medical and Veterinary Entomology 2: 397-399.

Crosskey, R. W. (ed.) 1990. The Natural History of Blackflies. Chichester: John Wiley \& Sons.

Davies, L. 1974. Evolution of larval head - fans in Simuliidae (Diptera) as inferred from the structure and biology of Crozetia crozetensis (Womersley) comparedwith other genera. Zoological Journal of the Linnean Society of London 55: 193-224.

Davies, D. M. and Peterson, B. V. 1956. Observations on the mating, feeding, ovarian development, and oviposition of adults (Simuliidae, Diptera). Canadian Journal of Zoology 34: 615-655.

Jensen, F. 1997. Diptera Simuliidae, Blackflies. Aquatic Insects of North Europe 2: 209-241.

Kaplich, V. M. and Skulovec, M. B. 2000. Bloodsucking black flies (Diptera: Simulidae) of the Belarus. Minsk: Tanka Publ. (in Russian).

Nicholson, H. P. and Mickel, C. E. 1950. The black flies of Minnesota (Simuliidae). University of Minnesota Agricultural Experiment Station Technical Bulletin 192: 1-64.
Thornhill, R. and Alcock, J. 1983. The Evolution of Insect Mating Systems. Cambridge, MA: Harvard University Press.

Tompkins, L., Hall, J. C. and Hall, L. M. 1980. Courtship stimulating volatile compounds from normal and mutant Drosophila. Journal of Insect Physiology 27: 17-21.

Twin, C. R. 1936. The blackflies of eastern Canada (Simuliidae, Diptera). Part I. Canadian Journal of Research (D) 14: 97-130.

Usova, Z. V. 1980. About swarms and copulation (Diptera, Simuliidae) in the Karelia and Murmansk region. In: Bloodsucking arthropods of European North, pp. 40-47. Petrozavodsk (in Russian).

Yankovsky, A. V. 2002. Identification book of the blackflies (Diptera: Simuliidae) of Russia and adjacent territories (former USSR). St. Petersburg: Zoological Institute of the Russian Academy of Sciences. [Янковский, А. В. 2002. Определитель мошек (Diptera: Simuliidae) России и сопредельных территорий бывшего СССР. Санкт-Петербург: Зоологический Институт Российской Академии Наук.]

\section{UPINIŲ MAŠAlŲ SIMULIUM LINEATUM (Diptera: SimuliIdAe) PREKOPUliaCinė ELGSENA, PORAVIMASIS IR LYČIU SANTYKIS NATŪRALIOSE SĄLYGOSE}

\section{Baužienè, V. Būda}

\section{SANTRAUKA}

Tirta stenogaminių upinių mašalų (Diptera: Simuliidae) Simulium lineatum (Meigen, 1984) prekopuliacinè ir poravimosi elgsena gamtoje. Patinai randami pavieniui, susitelkę i nedideles grupeles (vidutiniškai po 1,8 $\pm 1,1$ individus) ant ajerų (augalo aukštis virš vandens iki $50 \mathrm{~cm}$ ) lapų, arba i sankaupas (vidutiniškai po $6,0 \pm$ 3,3 individus) ant švendrų (augalo aukštis virš vandens iki $100 \mathrm{~cm}$ ). Patelès aptinkamos tiek tarp sankaupas sudarančiu, tiek su pavieniais patinais. Poligininiai patinai demonstruoja tuoktuvių elgseną (priartèja, liečia, bando kopuliuoti) ne tik su patelèmis, bet ir su patinais. Lietimo ir bandymo kopuliuoti trukmė skiriasi: su patele $-13,5$ $\pm 4,5 \mathrm{~s}$; su patinu $-6,9 \pm 2,4 \mathrm{~s}$. Vidutinè kopuliacijos trukmè siekia 5,4 $\pm 1,1 \mathrm{~min}$. S. lineatum lyčių santykis suaugèlių skraidymo sezono metu pastumtas patinų link: pirmoje sezono pusèje siekia 1:1,08 (patinų išsirita 4\% daugiau), antroje sezono pusejje patikimai daugiau ritasi patinų - 1:1,4 (patinų išsirita 16\% daugiau). 